Огляди літератури, оригінальні дослідження, погляд на проблему

удК 615-089.44/.816-06:617.586:616.379-008.64

DOI 10.11603/1811-2471.2017.v1.i3.8174

\title{
ОСОБЛИВОСТІ ВПЛИВУ ВАКУУМНОЇ ТЕРАПІЇ НА ДИНАМІКУ КЛІНІЧНОЇ КАРТИНИ РАНОВИХ ДЕФЕКТІВ У ХВОРИХ НА СИНДРОМ СТОПИ ДІАБЕТИКА
}

ДВНЗ «Тернопільський державний медичний університет імені І. Я. Горбачевського МОз України»

РЕЗЮМЕ. Метою роботи було вивчити динаміку клінічної картини ранових дефектів у хворих на синдром стопи діабетика.

Матеріал і методи. На основі обстеження та лікування 131 хворого на цукровий діабет, ускладнений синдромом діабетичної стопи, серед яких було 58 хворих з невропатично-інфікованою формою, 43 хворих з ішемічно-гангренозною формою, та 30 хворих контрольної групи (по 15 з кожною формою), вивчено вплив застосування вакуумтерапії на динаміку клінічної картини ранових дефектів. 3 метою контролю за клінічним перебігом гострого ранового процесу вивчали динаміку больового синдрому, місцевих ознак запального процесу, терміни розвитку грануляційної тканини та об'єм рани, показники мікроциркуляції, швидкість епітелізації та загоєння ран. Вираженість больового синдрому визначали за допомогою Цифрової Рейтингової Шкали (Numerical Rating Scale, NRS). Baкуyм-терапію застосовували за допомогою вакуум-апарату «АГАТ-ДНІПРО» з використанням від'ємного тиску в діапазоні 80125 мм рт. ст. Хворим проводили загальне клініко-лабораторне та інструментальне обстеження.

Результати. Починаючи з 5 доби на тлі вакуумної терапії больовий синдром мав виражену тенденцію до зниження і склав у досліджуваній групі $(3,13 \pm 0,21)$ бала $(p<0,001)$, на 8 добу $-(1,12 \pm 0,08)$ бала $(p<0,001)$ і на $12-(0,81 \pm 0,02)$ бала $(p<0,001)$. Набряк м'яких тканин достовірно зменшувався в середньому на $(2,46 \pm 0,84)$ день $(p<0,01)$, гіперемія тканин на $(2,16 \pm 0,48)$ день $(p<0,01)$, інфільтрація тканин довкола рани на $(3,25 \pm 0,82)$ день $(p<0,01)$. У хворих основної групи активна крайова епітелізація розпочиналася на $(4,64 \pm 1,12)$ день. Вакуум-терапія ранових дефектів пришвидшує появу грануляційної тканини, у хворих з основної групи НІФ грануляції відмічали на $(4,61 \pm 0,96)$ день проти $(7,84 \pm 1,14)$ контрольної групи. У пацієнтів з основної групи ІГФ грануляції відмічали на $(6,53 \pm 1,14)$ день проти $(10,78 \pm 1,31)$ день контрольної групи. Використання вакуумної терапії ранових дефектів у хворих на ССД стимулює ріст грануляційної тканини, зменшує набряк тканин, покращує загальний стан пацієнтів, зменшує больовий синдром та нормалізує температуру тіла.

КлючОВІ СлОВА: цукровий діабет; синдром стопи діабетика; вакуумна терапія.

Вступ. На сьогодні, як свідчать дані досліджень експертів ВООЗ, кількість хворих на цукровий діабет (ЦД) у світі перевищує 120 млн і стрімко зростає, а до 2030 року на Землі буде понад 360 млн хворих $[1-3,5,8]$. Синдром стопи діабетика (ССД) виникає у 70-80\% хворих на ЦД, призводячи до утворення відкритих ранових дефектів та розвитку гнійно-некротичних уражень нижніх кінцівок, які у 50-80 \% хворих можуть бути причиною високих ампутацій. Однією із актуальних методик місцевого лікування ранових дефектів $\epsilon$ вакуум-терапія зі значним позитивним впливом на рановий процес, але вплив вакуум-терапії на зміну динаміки клінічної картини ран вивчено недостатньо, а тому вимагає подальших досліджень $[1,4,5-7,9]$.

Мета дослідження - вивчити вплив вакуумної терапії на динаміку клінічної картини ранових дефектів у хворих на синдром стопи діабетика.

Матеріал і методи дослідження. Робота ґрунтується на матеріалах комплексного обстеження та лікування 58 хворих з невропатично-інфікованою формою (НІФ), 43 хворих з ішемічногангренозною формою (ІГФ) ССД, та 30 хворих контрольної групи (по 15 з кожною формою), які впродовж 2013-2016 рр. перебували на стаціонарному лікуванні в клініці загальної хірургії
ДВНЗ «Тернопільський державний медичний університет імені І. Я. Горбачевського МОЗ України» (хірургічне відділення Тернопільської міської комунальної лікарні швидкої допомоги). У всіх паці$\epsilon$ ттів було отримано інформовану згоду на запропоновані дослідження та методи лікування. Контрольні групи склали по 15 пацієнтів з НІФ та ІГФ ураженнями, в лікуванні яких вакуумна терапія не використовувалася. Серед обстежених хворих чоловіків було 85 (64,9\%), жінок - 46 (35,1\%), віком від 48 до 72 років. Хворих на ЦД легкого ступеня було 18 , середньої тяжкості - 81, тяжкого 32. Середній вік пацієнтів склав $(64,7 \pm 4,5)$ роки. Стадія компенсації ЦД при поступленні діагностована у 45 хворих (34,3\%), субкомпенсації - у 67 (51,14\%), декомпенсації - у 19 (14,56 \%) пацієнтів. 3 метою контролю за клінічним перебігом гострого ранового процесу вивчали динаміку больового синдрому, місцевих ознак запального процесу (набряк стопи, гіперемія тканин), терміни розвитку грануляційної тканини та об'єм рани, показники мікроциркуляції, швидкість епітелізації та загоєння ран. Вираженість больового синдрому визначали за допомогою Цифрової рейтингової шкали (Numerical Rating Scale, NRS) [6]. Хворим проводили загальне клініко-лабораторне та інструментальне обстеження, отримані результа- 
Огляди літератури, оригінальні дослідження, погляд на проблему

ти обробляли статистично з використанням критерію Стьюдента, за допомогою комп'ютерних програм S-PLUS 2000, STATISTICA, Excell. Результати вважали достовірними при значеннях $р<0,05$. Вакуум-терапію застосовували за допомогою вакуум-апарату «АГАТ-ДНІПРО», з використанням від'ємного тиску в діапазоні 80-125 мм рт. ст. Для накладання вакуумних пов'язок використовували стандартні комплекти виробництва компанії V.A.C. Granu Foam Dressing (USA).

Результати й обговорення. Хворим з рановими дефектами проводили хірургічну обробку ран з наступним застосуванням вакуумної терапії одразу після оперативного втручання (сила вакууму 50-80 мм рт. ст.) або на наступний день (сила вакууму 100-120 мм рт. ст.). При поступленні ін- тенсивність больового синдрому у хворих на ССД контрольної та основної груп практично не відрізнялася. При НІФ ССД становив в середньому $(6,82 \pm 0,76)$ бала (контроль $-6,73 \pm 0,84)$, а у пацієнтів з ІГФ - $(8,92 \pm 0,81)$ бали (контроль - 8,84 $\pm 0,65)$ $(p<0,5)$. Менша вираженість больового синдрому у пацієнтів з НІФ пояснюється наявністю периферійної нейропатії, тоді як у хворих з ІГФ больовий синдром формується не лише за рахунок гнійнонекротичного процесу, а й за рахунок хронічної артеріальної недостатності.

На першу добу післяопераційного періоду больовий синдром не оцінювали, оскільки ще була залишкова дія анестезуючих препаратів. Тому його аналіз ми проводили на 2, 5, 8 та 12 доби (табл. 1).

Таблиця 1. Вплив вакуумної терапії на динаміку больового синдрому у хворих на ССД

\begin{tabular}{|c|c|c|c|c|c|}
\hline $\begin{array}{c}\text { Група обстежених } \\
\text { хворих }\end{array}$ & $\begin{array}{c}\text { На момент } \\
\text { поступлення }\end{array}$ & $\begin{array}{c}2 \text { доба } \\
\text { після операції }\end{array}$ & $\begin{array}{c}5 \text { доба } \\
\text { після операції }\end{array}$ & $\begin{array}{c}8 \text { доба } \\
\text { після операції }\end{array}$ & $\begin{array}{c}12 \text { доба } \\
\text { після операції }\end{array}$ \\
\hline \multicolumn{6}{|c|}{ НІФ СДС } \\
\hline $\begin{array}{l}\text { Контроль } \\
(n=15)\end{array}$ & $6,73 \pm 0,84$ & $\begin{array}{c}6,57 \pm 0,54 \\
p<0,5^{*}\end{array}$ & $\begin{array}{c}5,76 \pm 0,47 \\
p<0,5\end{array}$ & $\begin{array}{c}3,34 \pm 0,28 \\
p<0,001\end{array}$ & $\begin{array}{c}1,82 \pm 0,12 \\
p<0,001\end{array}$ \\
\hline $\begin{array}{l}\text { Основна група } \\
(n=58)\end{array}$ & $6,82 \pm 0,76$ & $\begin{array}{c}5,88 \pm 0,47 \\
p<0,2\end{array}$ & $\begin{array}{c}3,13 \pm 0,21 \\
p<0,001\end{array}$ & $\begin{array}{c}1,12 \pm 0,08 \\
p<0,001\end{array}$ & $\begin{array}{c}0,81 \pm 0,02 \\
p<0,001\end{array}$ \\
\hline \multicolumn{6}{|c|}{ ІГФ СДС } \\
\hline $\begin{array}{l}\text { Контроль } \\
(n=15)\end{array}$ & $8,84 \pm 0,65$ & $\begin{array}{c}8,26 \pm 0,64 \\
p<0,5\end{array}$ & $\begin{array}{c}7,43 \pm 0,72 \\
p<0,5\end{array}$ & $\begin{array}{c}4,61 \pm 0,58 \\
p<0,001\end{array}$ & $\begin{array}{c}2,78 \pm 0,36 \\
p<0,001\end{array}$ \\
\hline $\begin{array}{l}\text { Основна група } \\
(n=43)\end{array}$ & $8,92 \pm 0,81$ & $\begin{array}{c}7,91 \pm 0,53 \\
p<0,5\end{array}$ & $\begin{array}{c}5,26 \pm 0,56 \\
p<0,05\end{array}$ & $\begin{array}{c}2,73 \pm 0,32 \\
p<0,001\end{array}$ & $\begin{array}{c}1,62 \pm 0,08 \\
p<0,001\end{array}$ \\
\hline
\end{tabular}

Примітка. * p - порівняння з відповідними контрольними групами на етапах лікування.

У хворих з НІФ ураження на 2 добу післяопераційного періоду відмічалося зниження больового синдрому, однак воно було статистично недостовірним $(p<0,2)$. Починаючи з 5 доби больовий синдром мав виражену тенденцію до зниження на тлі вакуумної терапії і склав у досліджуваній групі $(3,13 \pm 0,21)$ бала $(p<0,001)$, на 8 добу $-(1,12 \pm 0,08)$ бала $(p<0,001)$ і на $12-(0,81 \pm 0,02)$ бала $(p<0,001)$.

Достовірне зниження больового синдрому після оперативного втручання на тлі вакуумної терапії у хворих з ІГФ ураження відмічено на 5 добу післяопераційного періоду, хоча ця тенденція була менш вираженою: на 5 добу показник склав $(5,26 \pm 0,56)$ бала $(p<0,05)$, на $8-(2,73 \pm 0,32)$ бала $(p<0,001)$, на $12-(1,62 \pm 0,08)$ бала $(p<0,001)$. Однак у 14 хворих з 3 ступенем ХАН застосування вакуумної терапії призвело до посилення больового синдрому. Це змусило нас зменшити від'ємний тиск в системі до 80-90 мм рт. Ст., що, разом з прийомом аналгетиків, дозволило купірувати біль.

Отримані дані свідчать, що вакуумна терапія в післяопераційному періоді у хворих на ССД сприяє швидшому зменшенню больового синдрому, що позитивно впливає на загальний та пси- хоемоційний стан пацієнтів. Клінічними показниками сприятливого перебігу ранового процесу слугувало купірування набряку, гіперемії стопи та інфільтрації країв ранового дефекту, поява грануляційної тканини та крайової епітелізації.

Аналіз впливу вакуумної терапії на клінічний перебіг гострих ранових процесів показав достовірне покращення показників останнього у хворих на ССД, незалежно від патогенетичної форми. Вже на 2-3 добу лікування вакуумом спостерігалося достовірне зменшення місцевих проявів гострого запального процесу. У пацієнтів з НІФ ураження і набряк м'яких тканин достовірно зменшувалися в середньому на $(2,46 \pm 0,84)$ день $(p<0,01)$, гіперемія тканин на $(2,16 \pm 0,48)$ день $(p<0,01)$, інфільтрація тканин довкола рани - на $(3,25 \pm 0,82)$ день $(p<0,01)$ (табл. 2).

У пацієнтів з ІГФ ССД набряк м'яких тканин достовірно купірувався на $(2,52 \pm 0,42)$ день $(p<0,01)$, гіперемія тканин - на $(3,12 \pm 0,64)$ день $(p<0,01)$, інфільтрація тканин довкола рани -на $(3,96 \pm 0,84)$ день $(p<0,05)$. У всіх хворих зникли явища лімфангіїту та лімфаденіту. Також пацієнти відмічали значне покращення загального стану, зменшення больо- 
Огляди літератури, оригінальні дослідження, погляд на проблему

Таблиця 2. Клінічні ознаки перебігу ранового процесу у хворих на ССД на тлі вакуумної терапії

\begin{tabular}{|c|c|c|c|c|}
\hline Клінічні ознаки ранового процесу & $\begin{array}{c}\text { НІФ, } \\
\text { контрольна група } \\
(n=15)\end{array}$ & $\begin{array}{c}\text { НІФ, } \\
\text { основна група } \\
(n=58)\end{array}$ & $\begin{array}{c}\text { ІГФ, } \\
\begin{array}{c}\text { контрольна група } \\
(n=15)\end{array}\end{array}$ & $\begin{array}{c}\text { ІГФ, } \\
\text { основна група } \\
(n=43)\end{array}$ \\
\hline $\begin{array}{l}\text { Купірування набряку тканин, } \\
\text { днів }\end{array}$ & $5,84 \pm 0,72$ & $\begin{array}{c}2,46 \pm 0,84 \\
p<0,01 *\end{array}$ & $4,83 \pm 0,87$ & $\begin{array}{c}2,52 \pm 0,42 \\
p<0,01\end{array}$ \\
\hline $\begin{array}{l}\text { Купірування гіперемії тканин, } \\
\text { днів }\end{array}$ & $4,71 \pm 0,87$ & $\begin{array}{c}2,16 \pm 0,48 \\
p<0,01\end{array}$ & $5,78 \pm 0,62$ & $\begin{array}{l}3,12 \pm 0,64 \\
p<0,01\end{array}$ \\
\hline $\begin{array}{l}\text { Купірування інфільтрації країв рани, } \\
\text { днів }\end{array}$ & $6,43 \pm 0,78$ & $\begin{array}{c}3,25 \pm 0,82 \\
p<0,01\end{array}$ & $7,42 \pm 1,38$ & $\begin{array}{c}3,96 \pm 0,84 \\
p<0,05\end{array}$ \\
\hline $\begin{array}{l}\text { Поява грануляцій, } \\
\text { днів }\end{array}$ & $7,84 \pm 1,14$ & $\begin{array}{l}4,61 \pm 0,96 \\
p<0,05\end{array}$ & $10,78 \pm 1,31$ & $\begin{array}{c}6,53 \pm 1,14 \\
p<0,02\end{array}$ \\
\hline $\begin{array}{l}\text { Поява крайової епітелізації, } \\
\text { днів }\end{array}$ & $9,58 \pm 0,69$ & $\begin{array}{c}7,64 \pm 0,12 \\
p<0,01\end{array}$ & $12,65 \pm 0,96$ & $\begin{array}{l}8,15 \pm 0,47 \\
p<0,001\end{array}$ \\
\hline
\end{tabular}

Примітка. * р - порівняння між відповідними контрольними та групами обстеження.

вого синдрому, нормалізацію температури тіла, покращення сну та апетиту, тоді як у контрольних групах ці показники стабілізувалися лише на 5-6 добу лікування.

У хворих з НІФ ССД формування грануляційної тканини розпочиналося з $(4,61 \pm 0,96)$ дня $(p<0,05)$, а до $(6,43 \pm 0,48)$ дня ранові дефекти були готові до проведення пластичного закриття одним із методів пластичної хірургії (накладання вторинних швів, автодермопластика) (контрольна група $(9,42 \pm 1,46)$ день). У пацієнтів з ІГФ ССД формування грануляційної тканини розпочиналося з $(6,53 \pm$ $1,14)$ дня $(p<0,02)$ і ранові дефекти були готові до пластичного закриття на $(8,76 \pm 1,25)$ день (конт-

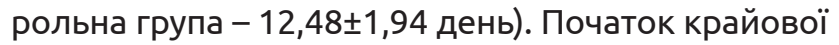
епітелізації ранових дефектів у пацієнтів контрольної групи з НІФ діагностовано на $(9,58 \pm$ $0,69)$ день. При подальшому дослідженні швидкості епітелізації за методикою Л. Н. Попової встановлено, що в контрольній групі цей показник склав в перші 4-5 днів в середньому 1,8 \%, а починаючи з 7-8 доби - 2,6 \% щоденно.

У хворих основної групи активна крайова епітелізація розпочиналася на $(4,64 \pm 1,12)$ день. Швидкість епітелізації на 3-4 день становила 2,9 \%, а на 6-7 добу - 3,9 \% щоденно. У пацієнтів контрольної групи з ІГФ ураження поява активної крайової епітелізації діагностована на $(12,65 \pm 0,96)$ день і швидкість епітелізації на 4-5 день склала 0,9 \%, а 3 7-8 дня - 1,3 \% щоденно. У хворих основної групи цей показник був наступним: поява активної крайової епітелізації - на $(6,15 \pm 0,47)$ день, з 3-4 дня 1,8 \%, з 6-7 дня - 2,8 \% щоденно.

Поряд з цим відмічалося і достовірне зменшення об'єму ранових дефектів при НІФ ураження, який мав швидшу динаміку у хворих основної групи. Так, у контрольній групі середній об'єм ран після хірургічного втручання склав $(16,26 \pm 0,43)$ см $^{3}$, 3 подальшим зменшенням на 4-5 день до $(13,46 \pm 0,36)$ см$^{3}$ (на 17,22 \%), та на 7-8 добу - до

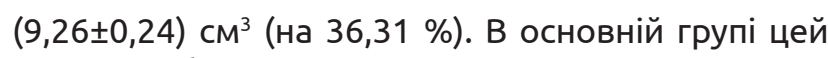
показник був наступним: після хірургічного втручання- $(18,96 \pm 0,46) \mathrm{CM}^{3}$, на 4-5 день- $(11,14 \pm 0,24) \mathrm{CM}^{3}$ (на 41,24 \%), на 7-8 добу - $(5,28 \pm 0,12)$ см³ $^{3}$ (на $72,15 \%$ ). У пацієнтів з ІГФ ССД динаміка зменшення об'єму ран була наступною. В контрольній групі після хірургічного втручання цей показник склав $(15,84 \pm 0,32) \mathrm{CM}^{3}$, на 4-5 день - $(12,18 \pm 0,56) \mathrm{CM}^{3}$ (на

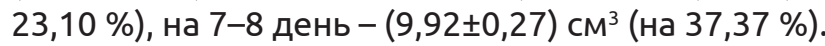
В основній групі відповідно - після операції $(16,92 \pm 0,18) \mathrm{cm}^{3}$, на 4-5 день - $(10,28 \pm 0,24) \mathrm{cm}^{3}$ (на $39,24 \%)$, на 7-8 день - $(7,82 \pm 0,68)$ см $^{3}$ (на $50,63 \%)$.

Отже, використання вакуумної терапії ранових дефектів у хворих на ССД стимулює ріст грануляційної тканини, прискорюючи динаміку зменшення їх площі та об'єму.

Висновки. 1. Вакуумна терапія в післяопераційному періоді у хворих на ССД як з НІФ, так і з ІГФ, зменшує больовий синдром починаючи вже з 2 дня застосування, на 5 добу у хворих з НІФ основної групи становив $(3,13 \pm 0,21)$ бала проти $(5,76 \pm 0,47)$ балів контрольної групи. А у пацієнтів з ІГФ основної групи - $(5,26 \pm 0,56)$ балів проти $(7,43 \pm 0,72)$ балів контрольної групи. На 12 добу вакуум-терапії больовий синдром зменшився: у хворих з НІФ основної групи до $(0,81 \pm 0,02)$ бала проти $(1,82 \pm 0,12)$ бала контрольної, та у хворих 3 ІГФ основної групи - $(1,62 \pm 0,08)$ бала проти $(2,78 \pm 0,36)$ контрольної.

2. Зменшення місцевих проявів гострого запального процесу відмічали вже на 2-3 добу лікування вакуумом. У хворих з НІФ набряк м'яких тканин зменшувався в середньому на $(2,46 \pm 0,84)$ день основної групи проти $(5,84 \pm 0,72)$ контрольної групи, а гіперемія тканин - на $(2,16 \pm 0,48)$ день проти $(4,71 \pm 0,87)$ контрольної групи, інфільтрація тканин довкола рани зменшувалась на $(3,25 \pm 0,82)$ день проти $(6,43 \pm 0,78)$ день у контрольній групі. У хворих з ІГФ набряк зменшувався на $(2,52 \pm 0,42)$ день 
Огляди літератури, оригінальні дослідження, погляд на проблему

основної групи проти $(4,83 \pm 0,87)$ контрольної групи, гіперемія тканин - на $(3,12 \pm 0,64)$ день проти $(5,78 \pm 0,62)$ контрольної, інфільтрація тканин зменшувалась на $(3,96 \pm 0,84)$ день проти $(7,42 \pm 1,38)$ день в контрольній групі.

3. Вакуум-терапія ранових дефектів пришвидшує появу грануляційної тканини, у хворих 3 основної групи НІФ грануляції відмічали на $(4,61 \pm$ $0,96)$ день проти $(7,84 \pm 1,14)$ контрольної групи. У пацієнтів з основної групи ІГФ грануляції відміча- ли на $(6,53 \pm 1,14)$ день проти $(10,78 \pm 1,31)$ день контрольної групи.

Перспективи подальших досліджень. Отримані результати відкривають перспективи подальшого удосконалення вакуумної терапії відкритих ранових дефектів у хворих на цукровий діабет, ускладнений синдромом стопи діабетика. Дослідження доцільно спрямувати на вивчення впливу комбінації вакуум-терапії та біофорезу на клінічну картину ран.

\section{ЛІТЕРАТУРА}

1. Абаев Ю. К. Раны и раневая инфекция. Справочник хирурга / Ю. К. Абаев. - Ростов на Дону : Феникс, 2006. -427 с.

2. Вакуум-інстиляційна терапія у хворих синдромом діабетичної стопи / О. М. Бєсєдін, Ю. Ю. Малюк, Л. І. Карпенко [та ін.] // Клінічна хірургія. - 2014. - № 11 (3). C. 8-10.

3. Синдром диабетической стопы в клинической практике / В. Н. Оболенский, Т. В. Семенова, П. Ш. Леваль, А. А. Плотников // Русский мед. журнал. - 2010. № 2. - С. 45-58.

4. Удовиченко О. В. Диабетическая стопа / О. В. Удовиченко, Н. М. Грекова. - М. : Практическая медицина, 2010. -272 c.

5. Храмилин В. Н. Современные аспекты местного лечения хронических ран нижних конечностей у больных сахарным диабетом / В. Н. Храмилин // Сахарный диабет. - 2005. - № 4. - С. 1-8.

6. Assessment of pain / H. Breivik, P. C. Borchgrevink, S. M. Allen [et al.] // British Journal of Anaesthesia. - 2008. Vol. 101, No. 1. - P. 17-24.

7. Poly (ADP-ribose) polymerase is activated in subjects at risc of developing type 2 diabetes and is associated with impaired wascular reactivity / C. Szabo, A. Zanchi, K. Komjati [et al.] // Circulation. - 2002. - Vol. 106. - P. 2680-2686.

8. Suzuki E. Prevalence and major risk factors of reduced flow volume in lower extremities with normal anklebrechial index in Japanese patients with type 2 diabetes / E. Suzuki // Diabetes Care. - 2003. - P. 1443-1446.

9. The Foot in Diabetes, 3d. Ed. A. J .M. Boulton, H. Connor, 41. P. Cavanagh (eds). - J. Wiley \& Sons. Inc., 2000. - 364 p.

\section{REFERENCES}

1. Abaev, Yu.K. (2006). Rany i ranevaya infektsiya. Spravochnik khirurga [Wounds and wound infection. Directory of a surgeon]. Rostov on the Don: Phoenix [in Russian].

2. Biesiedin, O.M., Maliuk, Yu.Yu., \& Karpenko, L.I. (2014). Vakuum-instyliatsiina terapiia u khvorykh syndromom diabetychnoi stopy [Vacuum-instillation therapy for patients with diabetic foot syndrome]. Klinichna khirurhiia Clinical Surgery, 11 (3), 8-10 [in Ukrainian].

3. Obolenskiy, V.N., Semenova, T.V., Leval, P.S., \& Plotnikov, A.A. (2010). Sindrom diabeticheskoy stopy v klinicheskoy praktike [Diabetic foot syndrome in clinical practice]. Russkiy meditsinskiy zhurnal - Russian Medical Journal, 2, 45-58 [in Russian].

4. Udovichenko, O.V., \& Grekova, N.M. (2010) Diabeticheskaya stopa [Diabetic foot]. Moscow: Practical medicine [in Russian].

5. Khramilin, V.N., (2005) Sovremennye aspekty mestnogo lecheniya khronicheskih ran nizhnikh konech-

nostey u bolnykh sakharnym diabetom [Modern aspects of local treatment of chronic lower limb wounds in patients with diabetes mellitus]. Sakharnyy diabet - Diabetes Mellitus, 4, 1-8 [in Russian].

6. Breivik, H., Borchgrevink, P.C., \& Allen, S.M. (2008). Assessment of pain. British Journal of Anaesthesia, $101(1), 17-24$

7. Szabo, C., Zanchi, A. \& Komjati, K. (2002). Poly (ADP-ribose) polymerase is activated in subjects at risc of developing type 2 diabetes and is associated with impaired wascular reactivity. Circulation, 106, 2680-2686.

8. Suzuki, E. (2003). Prevalence and major risk factors of reduced flow volume in lower extremities with normal ankle-brechial index in Japanese patients with type 2 diabetes. Diabetes Care, 1443-1446.

9. Boulton, A.J.M., Connor, H., \& Cavanagh, P. (Eds.). (2000). The foot in diabetes, 3d. J. Wiley \& Sons. Inc. 


\title{
Огляди літератури, оригінальні дослідження, погляд на проблему \\ ОСОБЕННОСТИ ВЛИЯНИЯ ВАКУУМНОЙ ТЕРАПИИ НА ДИНАМИКУ КЛИНИЧЕСКОЙ КАРТИНЫ РАНЕВЫХ ДЕФЕКТОВ У БОЛЬНЫХ С СИНДРОМОМ ДИАБЕТИЧЕСКОЙ СТОПЫ
}

๑) А. В. Павлишин

\author{
Тернопольский государственный медицинский университет имени И. Я. Горбачевского
}

РЕЗЮМЕ. Целью работы было изучить динамику клинической картины раневых дефектов у больных синдромом стопы диабетика.

Материал и методы. На основании обследования и лечения 131 больного сахарным диабетом с синдромом диабетической стопы, среди которых было 58 больных с нейропатической-инфицированной формой, 43 больных с ишемической-гангренозной формой, и 30 больных контрольной группы (по 15 каждой формы) изучено влияние применения вакуум терапии на динамику клинической картины раневых дефектов. С целью контроля за клиническим течением острого раневого процесса изучали динамику болевого синдрома, местных признаков воспалительного процесса, сроки развития грануляционной ткани и объем раны, показатели микроциркуляции, скорость эпителизации и заживления ран. Выраженность болевого синдрома определяли с помощью Цифровой рейтинговой шкалы (Numerical Rating Scale, NRS). Вакуум-терапию применяли с помощью вакуум-аппарата «АГАTДНЕПР», с использованием отрицательного давления в диапазоне 80-125 мм рт. ст. Больным проводили общее клинико-лабораторное и инструментальное обследование.

Результаты. Начиная с 5 дня на фоне вакуумной терапии болевой синдром имел выраженную тенденцию к снижению и составил в исследуемой группе $(3,13 \pm 0,21)$ балла $(p<0,001)$, на 8 сутки - $(1,12 \pm 0,08) 6$ блла $(p<0,001)$ и на 12 - $(0,81 \pm 0,02)$ балла $(p<0,001)$. Отек мягких тканей достоверно уменьшался в среднем на $(2,46 \pm 0,84)$ день $(p<0,01)$, гиперемия тканей - на $(2,16 \pm 0,48)$ день $(p<0,01)$, инфильтрация тканей вокруг раны - на $(3,25 \pm 0,82)$ день $(p<0,01)$. У больных основной группы активная краевая эпителизация начиналась на $(4,64 \pm 1,12)$ день. Вакуумтерапия раневых дефектов ускоряет появление грануляционной ткани, у больных основной группы НИФ грануляции отмечали на $(4,61 \pm 0,96)$ день против $(7,84 \pm 1,14)$ контрольной группы. У пациентов основной группы ИГФ грануляции отмечали на $(6,53 \pm 1,14)$ день против $(10,78 \pm 1,31)$ день контрольной группы. Использование вакуумной терапии раневых дефектов у больных ССД стимулирует рост грануляционной ткани, уменьшает отек тканей, улучшает общее состояние пациентов, уменьшает болевой синдром и нормализует температуру тела.

КЛЮЧЕВЫЕ СЛОВА: сахарный диабет; синдром стопы диабетика; вакуумная терапия.

\section{FEATURES OF THE INFLUENCE OF VACUUM THERAPY ON THE DYNAMICS OF THE CLINICAL PICTURE OF WOUND DEFECTS IN PATIENTS WITH DIABETIC FOOT SYNDROME}

@A. V. Pavlyshyn

\section{Horbachevsky Ternopil State Medical University}

SUMMARY. The aim of the work was to study the dynamics of the clinical picture of wound defects in patients with diabetic foot syndrome.

Materials and Methods. On the basis of examination and treatment of 131 patients with diabetes mellitus complicated by diabetic foot syndrome we studied the effect of vacuum therapy on the dynamics of the clinical picture of wound defects. In order to control the clinical course of an acute wound process, the dynamics of the pain syndrome, local signs of the inflammatory process, the timing of granulation tissue development and the amount of wound, microcirculation, the rate of epithelization, and wound healing were studied. The severity of the pain was determined using the Numerical Rating Scale. Vacuum therapy was used with the vacuum apparatus "AGAT-DNIPRO" (80-125 mm. $\mathrm{Hg}$ ). Patients underwent a general clinical-laboratory and instrumental examination.

Results. Starting from the 5th day, on the background of vacuum therapy, the pain syndrome had a pronounced tendency to decrease and was in the study group $(3.13 \pm 0.21)(p<0.001)$, at the 8th day $-(1.12 \pm 0.08)$ points $(p<0.001)$ and on the 12 th $-(0.81 \pm 0.02)(p<0.001)$. The edema of soft tissues significantly decreased on average $(2.46 \pm 0.84)$ days ( $p<0.01)$, tissue hyperemia on $(2.16 \pm 0.48$ ) days $(p<0.01)$, infiltration tissues around the wound on $(3.25 \pm 0.82)$ days $(p<0.01)$. In patients with the main group, active regional epithelization began on $(4.64 \pm 1.12)$ days. Vacuum therapy of wound defects accelerates the appearance of granulation tissue; patients with the main group of NIF granulation were marked at $(4.61 \pm 0.96)$ days versus $(7.84 \pm 1.14)$ control groups. In patients with the main group, the granulation was marked at $(6.53 \pm 1.14)$ days versus $(10.78 \pm 1.31)$ days of the control group. The use of vacuum therapy for wound defects in patients with CCD stimulates the growth of granulation tissue, reduces tissue swelling, improves the general condition of patients, reduces pain syndrome and normalizes body temperature.

KEY WORDS: diabetes mellitus; diabetic foot syndrome; vacuum therapy. 